\title{
Factors Affecting Islamic Social Reporting in the Halal Industry Sector
}

\author{
Budiandru \\ Universitas Muhammadiyah Prof. Dr. HAMKA, Indonesia \\ Email: budiandru@yahoo.com
}

Article History: Received: 10 November 2020; Revised 12 January 2021 Accepted: 27 January 2021; Published online: 5 April 2021

\begin{abstract}
Islamic social reporting is a measure of Islamic-based social performance reporting in each company. Increased disclosure of Islamic social interpretation will influence investor decisions. This study aims to analyze what factors influence the declaration of Islamic corporate social responsibility. The data used is the annual report of companies registered in the halal industry sector from 2013 to 2018 with 44 selected companies. This study uses a random effect model (REM). The analysis results show that the halal lifestyle, profitability, and leverage are significant in disclosing Islamic corporate social responsibility. Implementation of ISR disclosure as a form of accountability is based on principles and philosophies following Islamic Sharia. Therefore, companies must improve their financial performance to enhance corporate social responsibility disclosure quality, which is very important for stakeholders in investing.
\end{abstract}

Keywords: Islamic Social Reporting, Random Effect Model, Halal Lifestyle, Profitability, Leverage

\section{Introduction}

Corporate social responsibility or CSR has become increasingly important in recent years because the concept of CSR is at the core of corporate business ethics (Cooke, 2009). The main goal of CSR is to make the company not only on the single-bottom-line (SBL) concept in the company's financial records but also on the triple-bottomline (TBL) concept, which includes aspects of finance, social life, and the environment (Haniffa \& Cooke, 2005).

In addition to providing information about financial statements, companies are also required to give information on a company's social activities (Chen, Hung, \& Wang, 2018; Dagilienè, 2013; Leitoniene \& Sapkauskiene, 2015). This serves as a corporate responsibility to disclose social and environmental information that is reported voluntarily (Nazari, Hrazdil, \& Mahmoudian, 2017; Zheng \& Ren, 2019). Information about corporate social responsibility (CSR) is published in its annual report or a separate social report from the company's annual report (Wuttichindanon, 2017). The company's annual report must reflect social responsibility, even companies whose business activities are in the field and or related to natural resources so that they need to carry out social responsibility (Boubakary \& Moskolaï, 2016; Castejón \& López, 2016; Sanclemente-Téllez, 2017). Otherwise, they will be subject to sanctions following statutory provisions. With this, companies are increasingly encouraged to report their CSR activities.

The number of companies that disclose CSR information in financial statements from year to year is increasing. Many companies are starting to realize that the implementation of CSR programs can be used as a business strategy in the company (Gorski, Fuciu, \& Croitor, 2014; Šontaitė-Petkevičienè, 2015). Senior executives and investors from various organizations make CSR a significant consideration in decision making (Frederiksen, 2018; Gras-Gil, Manzano, \& Fernández, 2016). CSR activities carried out by the company can show that the company is also concerned with the environment and the welfare of the surrounding community and its employees' well-being (Rodriguez-Fernandez, 2016; Sarkis \& Daou, 2013). And can improve the company's image, increase the accountability of an organization with the assumption that there is a social contract between the organization and the community, and provide information to investors (Dyck, Lins, Roth, \& Wagner, 2019; Sila \& Cek, 2017).

The concept of CSR is now used in conventional economics and has also developed into an Islamic economy. According to Sharia, the idea of CSR in Islam is closely related to companies that run their business. It can carry out social responsibility for their surrounding environment in an Islamic way (Yusuf, 2017). This development also has an impact on increasing public attention to sharia agencies or institutions. This indicates that the community's need for Islamic institutions is getting more significant from time to time. The Islamic capital market is an institution that plays an essential role in increasing the share of the Islamic market in companies looking to participate in the share of the Islamic market in Indonesia (Purwadi, 2017). 
Information about CSR in Islamic economics can increase investor attention to Islamic institutions or institutions (Zain, Darus, \& Ramli, 2015). In Indonesia, more and more companies are based on Sharia; this proves that the Islamic Economy is experiencing rapid development. To fulfill sharia-based reporting, Muslims began to develop corporate social responsibility reporting by sharia principles, also known as Islamic Social Reporting (ISR). ISR disclosure is a refinement of CSR disclosure, which adds some items not included in Islamic social reporting disclosures. With the development of companies that disclose CSR information also increases public attention towards Islamic institutions or institutions. The capital market as an institution and profession related to securities, in this case, is the Islamic capital market having an essential role in increasing the market share of Islamic securities in companies wishing to participate in the Islamic capital market.

Research using ISR as a benchmark for CSR has been carried out by Khairiyani and Mubyarto (2019), Hadinata (2019), Rizfani and Lubis (2019), Mubarok (2019), Adlan and Mawardi (2018), Pratama, Muchlis, and Wahyuni (2018), Cahya (2018), Prasetyoningrum (2018), Santoso and Dhiyaul-Haq (2017), Sulistyawati and Yuliani (2017). From previous studies, there is still no specific research in the halal industry sector. So this study aims to analyze what factors influence CSR in the industrial area. This research contributes, first adding a new perspective on CSR factors in the halal industry sector. Second, decision making in investing for policymakers. Third, enrich the CSR literature.

\section{Literature Review}

The development of Corporate Social Responsibility (CSR) in Indonesia has increased in quantity and quality compared to previous years. Islamic Social Reporting (ISR) is a standard for reporting the social performance of sharia-based companies. This index was developed based on reporting standards based on Accounting and Auditing Organizations for Islamic financial institutions (AAOIFI). Specifically, this index is an extension of social performance reporting standards that include public expectations about companies' role in the economy and the part of companies from a spiritual perspective (Indrawaty \& Wardayati, 2016). Besides, this index also emphasizes social justice related to the environment, minority rights, and employees.

Research related to ISR has been conducted by Khairiyani and Mubyarto (2019). They tested the influence of Islamic Corporate Social Responsibility (ICSR) on companies' financial performance listed on the Jakarta Islamic Index. ICSR is measured using indicators of investment, products, services, employees, community, environment, and corporate governance. Financial performance is measured by return on assets and return on equity. The results show that ICSR has been able to improve business performance.

Hadinata (2019) empirically tested ISR's effect on financial performance proxied by return on assets and profit-sharing ratios. This study used a sample of seven Islamic banks during the 2011-2016 period to obtain 42 observational data. The results showed that the ISR harms both returns on assets and profit-sharing ratios. Rizfani and Lubis (2019) analyze the disclosure of sharia corporate social responsibility and its factors. The data used is the annual report of companies listed on the Jakarta Islamic Index from 2012 to 2015. The results showed that company size has a positive effect, company age, and leverage has a significant negative impact on ISR disclosure. Simultaneously, the number of the board of commissioners and profitability does not affect the exposure of ISR.

Mubarok (2019) analyzes ISR disclosure and its impact on profitability at the Indonesian Sharia Commercial Bank. The results showed that: first, Good Corporate Governance (GCG) affects ISR. Second, financial factors have a positive influence on ISR. Third, GCG hurts profitability. Fourth, economic factors have a positive effect on profitability. Fifth, ISR affects profitability. Sixth, ISR mediates the relationship between GCG and financial factors with profitability. Adlan and Mawardi (2018) conducted a study to determine whether restrictions on interest-based debt and non-halal income restrictions have a significant effect on firm value. The companies studied were companies located in the Jakarta Islamic Index for the 2013-2018 period. The results showed that interest-based debt and non-halal income did not affect the company value partially or simultaneously.

Pratama, Muchlis, and Wahyuni (2018) tested and found the factors that influence the level of disclosure of social responsibility measured using Islamic Social Reporting on 11 Islamic commercial banks operating in Indonesia during 2013-2016. The results showed that profitability, bank size, institutional ownership, and leverage influence ISR disclosure level. For moderation tests, only profitability, institutional ownership, and leverage are moderated by independent commissioners in carrying out Islamic Social Reporting disclosures.

Cahya (2018) analyzes the presentation of sharia-based accountability to corporate stakeholders in the concept of Islamic Social Reporting (ISR) as an effort to provide relevant information following the spiritual needs of users of financial statements. The research results provide evidence that accountability is essential to make responsive attitudes towards the entity obtained and realize that there must be an attitude of responsibility that must be done. The implementation of ISR as a form of accountability is based on principles and philosophies that are extracted from the Qur'an and Sunnah as a guide in various life activities. Therefore, the implementation of 
ISR is based on spiritual and intellectual elements that are believed to solve and alleviate social problems, both within a business entity or in society, especially for community economic empowerment.

Prasetyoningrum (2018) identifies factors that influence the disclosure of ISR reporting in Islamic banking in Indonesia. The results showed that company size, profitability, leverage, and cost efficiency did not affect ISR, while the company's age factor statistically affected ISR. Santoso and Dhiyaul-Haq (2017) examine the factors that influence ISR in the Indonesian Islamic banking industry. This study uses profitability, awards, and types of ownership as determinants of ISR. Profitability is proxied by return on assets, while grants are identified by some CSR performance awards for one year. The type of ownership is classified into four, namely government, family, foreign, and institutional ownership. The results show that profitability, rewards, and kind of property do not partially affect ISR disclosure.

Sulistyawati and Yuliani (2017) empirically tested and analyzed company size, profitability, leverage, and commissioners' board for ISR disclosure. The results showed that the board of commissioners had a significant and positive effect on ISR. In contrast, profitability and leverage have no impact on ISR. Handayani (2017) measures the extent to which Islamic Social Reporting (ISR) is practiced by Islamic banks in Malaysia and examines the aspects of ISR that are most expressed in annual reports. This study uses 10 Islamic banks in Malaysia as a research sample. The results showed that the average level of ISR disclosure of Malaysian Islamic banks was $32.81 \%$, while the theme that had the highest level of exposure was the public with $10.77 \%$.

Kurniawati and Yaya (2017) analyzed the effect of board size, audit committee size, profitability, and environmental performance on Islamic Social Reporting (ISR) during 2011-2015 in 31 companies. The results show that the board of commissioners' size, profitability, and environmental performance have a positive influence on ISR disclosure. In contrast, the board of commissioners' independence and the audit committee do not affect ISR disclosure. Widayati and Sukmana (2017) examined the differences in the level of exposure of Islamic Social Reporting (ISR) of Islamic banking in Indonesia and Malaysia based on the ISR index. The results showed that the level of Islamic banking ISR exposure in Indonesia is better than the level of disclosure of Islamic banking ISR in Malaysia. Based on the results of hypothesis testing, it was found that there were significant differences in the level of exposure between Islamic banking in Indonesia and Malaysia.

Darus et al. (2014) investigated the ISR problem at Islamic commercial banks in Indonesia from 2007 to 2011. It was found that only two banks experienced a continuous increase in ISR disclosure. This study also reveals that the highest exposure is the company's vision, the board of directors, and top management. At the same time, the lowest disclosure is the environment, products, services, and agreements. Mallin, Farag, and Ow-Yong (2014) examined the relationship between corporate social responsibility (CSR) and Islamic banks' financial performance. They are using the ISR index, which covers ten dimensions with a sample of 90 Islamic banks in 13 countries. The ISR index shows that Islamic banks are involved in various social activities. There is a positive relationship between ISR disclosure and financial performance. Thus the exposure of ISR is determined by financial performance. El-Halaby and Hussainey (2015) examine the determinants of ISR disclosure in Islamic banks in 25 countries. The results found a meager disclosure rate of $26 \%$. Also, there is a positive relationship between the level of ISR and accounting standards, type of auditor, bank size, and Sharia audit departments' existence.

\section{Method}

This study uses annual data from the company's financial statements from 2013 to 2018, consisting of 44 companies engaged in the halal industry sector. This study uses a panel data approach that combines time-series data and crosses sections.

$$
\mathrm{ISR}_{\mathrm{it}}=\alpha_{0}+\beta_{1} \mathrm{HLS}_{\mathrm{it}}+\beta_{2} \mathrm{PRV}_{\mathrm{it}}+\beta_{3} \mathrm{LEV}_{\mathrm{it}}+\varepsilon_{\mathrm{it}}
$$

Where i represents the company, and t represents time. The data used in this study are Corporate Social Responsibility (CSR) using Islamic Social Reporting (ISR) indicators consist of underlying philosophy and values, management profile, interest-free and Islamically acceptable deals, development and social goals, employees, debtors, community, environment, shariah supervisory, well-being. Halal Lifestyle (HLS) using interest-based debt compared to total assets with a maximum tolerance limit of 45 percent, Profitability (PRV) using the return on assets (ROA) where the company's net profit is divided by total assets, and leverage (LEV) uses debt to equity ratio (DER) where total debt is divided by equity.

In resolving using panel data, several stages are carried out, starting with the classical assumption testing, including the data normality test, the multicollinearity test data, the heteroscedasticity test data, and the autocorrelation test. A normality test is conducted to test whether the standardized residual values in the regression model are normally distributed or not. The heteroscedasticity test aims to test whether, in the former model, there is an inequality of variance from the residual regression model. The multicollinearity test seeks to 
check whether there is a high or perfect correlation between the independent variables in the regression model formed. The autocorrelation test aims to determine whether there is a correlation between members of a series of observational data ordered by time or space. After examination, the conventional assumptions proceed with selecting the best model out of 3 trials, including pooled least square models, fixed-effect models, and random effect models.

\section{Result And Discussion}

Before testing the results to answer the study's objectives, examining the classical assumptions, based on the normality test histogram, it can be seen that the probability of Jarque-Bera $>0.05(0.600756>0.05)$ so that the data in this study have been distributed normally.

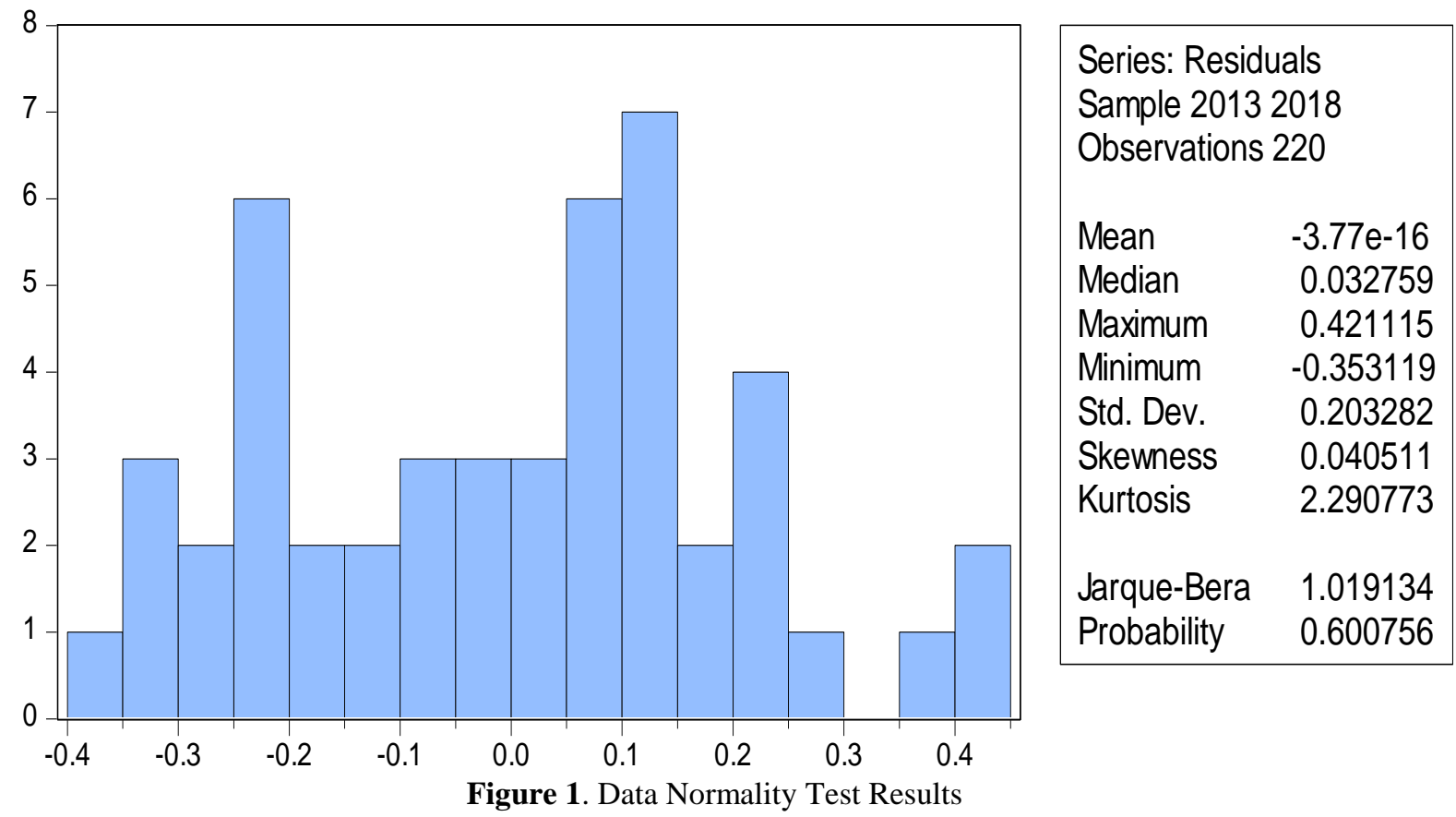

The multicollinearity test results use the value of Centered VIF, where the importance of all variables is smaller than the tolerance limit set, i.e., 10. Thus, the data used do not contain symptoms of multicollinearity.

Table 1. Multicollinearity Test Results

\begin{tabular}{|l|l|l|}
\hline Variable & Coefficient Variance & Centered VIF \\
\hline CSR & 2.546668 & 1.039800 \\
\hline HLS & 2.480050 & 1.048778 \\
\hline PRV & 0.269971 & 1.064200 \\
\hline LEV & 7.800342 & 1.017449 \\
\hline
\end{tabular}

Heteroscedasticity test results using the Breusch-Pagan-Godfrey test obtained an Obs* ${ }^{2}$ value of 17.69433 with a probability of 0.2305 . This result shows that the probability $>$ level of significance $(\alpha=5 \%)$. This means that residuals have homogeneous variety. Thus, the variables used do not contain heteroscedasticity.

Table 2. Heteroscedasticity Test Results

\begin{tabular}{|c|c|c|c|}
\hline \multicolumn{4}{|c|}{ Heteroskedasticity Test: Breusch-Pagan-Godfrey } \\
\hline F-statistic & 8.563309 & Prob. F(3,44) & 0.2101 \\
\hline Obs*R-squared & 17.69433 & Prob. Chi-Square(3) & 0.2305 \\
\hline Scaled explained SS & 9.595706 & Prob. Chi-Square(3) & 0.2223 \\
\hline
\end{tabular}

The autocorrelation test using the Lagrange multiplier is obtained from the Obs* $\mathrm{R}^{2}$ value of 23.49744 with a probability of 0.5470 . These results indicate that the two possibilities are higher than the significance (level $\alpha=$ $5 \%$ ). Thus it can be stated that between residual observations do not correlate with each other, so the variables do not contain autocorrelation. 
Table 3. Autocorrelation Test Results

\begin{tabular}{|l|c|l|c|}
\hline \multicolumn{4}{|l|}{ Breusch-Godfrey Serial Correlation LM Test: } \\
\hline F-statistic & 20.13856 & Prob. F(2,42) & 0.6320 \\
\hline Obs*R-squared & 23.49744 & Prob. Chi-Square(2) & 0.5470 \\
\hline
\end{tabular}

After testing the classical assumptions, select the best model by conducting a housman test and chow test. The model chosen from the panel data used is the random effect model, evidenced by the probability $>0.05$ in the chow test and the housman test $(1,0000>0.05)$.

Table 4. Selection of the Best Model

\begin{tabular}{|l|c|c|c|}
\hline \multicolumn{2}{|l|}{ Chow Test } & d.f. & Prob. \\
\hline Effects Test & Statistic & $(7,153)$ & 0.1000 \\
\hline Cross-section F & 11.339768 & 7 & 0.1000 \\
\hline Cross-section Chi-square & 63.107442 & Prob. \\
\hline Housman Test & Chi-Sq. Statistic & Chi-Sq. d.f & 1.0000 \\
\hline Test Summary & 0.000000 & 2 & \\
\hline Cross-section random &
\end{tabular}

Based on the results of the Random Effect Model, conclusions can be drawn.

$$
\mathrm{ISR}_{\mathrm{it}}=0.934587-0.096629 \mathrm{HLS}_{\mathrm{it}}+2.280007 \mathrm{PRV}_{\mathrm{it}}-0.001524 \mathrm{LEV}_{\mathrm{it}}+\varepsilon_{\mathrm{it}}
$$

The regression equation constant is positive at 0.934587 , meaning that if the value of the independent variables is 0 , then the value of the dependent variable (ISR) is 0.934587 . The regression coefficient for the halal lifestyle variable (HLS) is -0.096629 . This means that one unit's halal lifestyle decrease in the company's halal lifestyle will increase ISR disclosure of 0.096629, assuming the other independent variables are constant. The regression coefficient of the profitability variable (PRV) is 2.280007 , meaning that one unit's increase in company profitability will increase ISR disclosure of 2.280007, assuming the other independent variables are constant. The regression coefficient of the leverage variable (LEV) is negative at 0.001524 , meaning that one unit's increase in leverage will result in a decrease in ISR disclosure of 0.001524, assuming the other independent variables are constant. The F statistical test is used to test the significance of the regression parameters simultaneously. F statistical test shows whether all independent variables included in the model have a simultaneous influence on the dependent variable. Based on the REM regression model (Table 5), the significance value of 0.000049 is less than 0.05 , meaning that the halal lifestyle, profitability, and company leverage variables have a significant effect on ISR disclosure.

The t-test is used to determine whether the independent variable partially affects the dependent variable. The $\mathrm{t}$ count value of halal lifestyle (HLS) is -0.272507 , with a probability value of 0.0055 , which is less than 0.05 . This shows that the halal lifestyle has a negative and significant effect on ISR disclosure. This proves that companies' decision to manage interest-based debt is highly considered by companies in ISR disclosure (Adlan \& Mawardi, 2018). The regulation on limiting interest-based transactions on financial ratios is the limit point for the issuer to be declared as sharia-compliant or not (Soemitra, 2016). When referring to sharia rules in The Quran and hadith, usury-based transactions should not exist at all. However, if we see to the fiqh rule that what cannot be done thoroughly, do not entirely abandon it. So, limiting the number of usury-based transactions can be done. However, it must also be understood that these rules require Shari'a's implementation to the maximum extent possible. If it is related to the regulation of restrictions on riba-based transactions in the halal industry, the less interest-based debt and non-halal income levels the company has, it can be said that the company is getting better at applying the Islamic aspect in its activities (Alam, Akbar, Shahriar, \& Elahi, 2017; Ayedh, Shaharuddin, \& Kamaruddin, 2019; Md. Hashim, Habib, Isaacs, \& Gadhoum, 2017). The implementation of the Islamic elements that are getting better by the company will be a positive signal for investors who pay attention to the Islamic aspects of investing to increase company value and disclosure of corporate CSR reporting (Lys, Naughton, \& Wang, 2015). This means a negative relationship between the number of interest-based transactions and the disclosure of the company's ISR reporting. 
Table 5. Random Effect Model Results

\begin{tabular}{|l|l|l|l|l|}
\hline Variable & Coefficient & Std. Error & t-Statistic & Prob. \\
\hline C & 0.934587 & 0.135167 & 6.914311 & 0.0000 \\
\hline HLS & -0.096629 & 0.354592 & -0.272507 & 0.0055 \\
\hline PRV & 2.280007 & 4.810005 & 0.004734 & 0.0002 \\
\hline LEV & -0.001524 & 0.004073 & -0.374240 & 0.0000 \\
\hline R-squared & 0.963378 & Durbin-Watson stat & 0.439016 \\
\hline Adjusted R-squared & 0.962450 & \multicolumn{2}{|l|}{ Prob(F-statistic) } & 0.000049 \\
\hline
\end{tabular}

The t-value of profitability (PRV) is 0.004734 , with a probability value of 0.0002 less than 0.05 . This shows that profitability has a positive and significant effect on ISR disclosure. Profitability is a factor that makes management free and flexible to disclose social responsibility to shareholders. The higher the company profitability, the greater the disclosure of Islamic-based social information (ISR). This follows the theory of legitimacy, which explains that if an entity is operating following the prevailing norms in society, it will create a positive image and impact its financial performance, one of which is profit (Mandina, Maravire, \& Masere, 2014). This result is in line with Kurniawati and Yaya (2017) research that profitability is closely related to a company's management's effectiveness in determining strategic steps to gain profit. Companies with a higher profit rate will attract investors by providing better information to the public and other stakeholders by increasing social responsibility disclosure (Nainggolan \& Handoyo, 2019; Platonova, Asutay, Dixon, \& Mohammad, 2018; Salehi, Tarighi, \& Rezanezhad, 2019). This means that the higher the profitability, the more full the ISR disclosure will be (Mukhtaruddin, Saftiana, \& Dwikatama, 2018). High profitability means that companies will be more flexible and free in managing profits to disclose social responsibility to stakeholders (Hermawan \& Mulyawan, 2014). Hadinata (2019) also stated that the company's social performance would be viewed well by stakeholders to support its operational activities, which will increase its profits.

This study shows that profitability does not affect ISR disclosure. Because the company considers ISR to be a stakeholder need, especially Muslim stakeholders. The company assumes that when the financial condition experiences a profit or loss, the company will continue to carry out and disclose the ISR so that the company will get legitimacy from stakeholders. This is a form of accountability to Allah SWT and society and fulfills Muslim stakeholders' needs in decision-making. This is also stated by Hafidhuddin (2012), in Islamic sharia-oriented management, organizations or companies aim not only to seek the highest profit but also to provide benefits to the internal organization and external (environment). Therefore, companies that are members of Islamic Commercial Banks continue to make broader ISR disclosures to provide internal and external benefits to the company, even though the company experiences a decline in profit. This study's results are following research conducted by Othman et al. (2009), which states that the level of profitability should not affect the disclosure of ISR and Lestari (2016); companies that have high profits do not necessarily carry out many social activities because companies are more profit-oriented. Meanwhile, when the company gets low yields, there is a perception that reports users are happy to read good news about the company's performance in the social sector.

The $t$-value of leverage (LEV) is -0.374240 , with a probability value of 0.0000 , which is less than 0.05 . This shows that advantage has a negative and significant effect on the ISR disclosure. Leverage is a tool to measure how much a company is to creditors in financing company assets (Cheng, Business, Iowa, \& Campus, 2014). Companies with a high degree of leverage mean that they are very dependent on external loans to finance their assets (Onofrei, Tudose, Durdureanu, \& Anton, 2015). Meanwhile, companies with a low level of force are more likely to finance their assets with their capital (Dyck et al., 2019). Thus, the degree of corporate leverage reflects the company's financial risk (Innocent, Ikechukwu, \& Nnagbogu, 2014). Agency theory predicts that companies with higher leverage ratios will disclose more information because firms' agency costs with such capital structures are higher (Riantani \& Nurzamzam, 2015). Social responsibility reporting using the Islamic Social Reporting index is a strategy used by Islamic banks to convince and gain legitimacy from creditors regarding company compliance (Pratama et al., 2018). This study's results are in line with research conducted by (Rizfani \& Lubis, 2019), which states that a small debt company will influence its decision to improve Sharia's social performance reporting.

Based on the hypothesis testing, leverage does not affect the ISR disclosure. This is due to the consumer's ability to obtain information and other disclosures apart from the annual report. So that creditors can get information and other disclosures through direct question and answer to the company, agreements, interim company reports, or additional supplementary reports/information such as data or schedules provided by the company or ask management for an explanation of financial information and a discussion of the significance of 
the financial statement. This makes investors aware of information other than the annual report, resulting in less demanding for a complete ISR disclosure to the company. So when the level of leverage is high or low, it will not affect the ISR disclosure (Chow et al., 1987). This is the risk of increasing information asymmetry and uncertainty about the company's prospects. These results are consistent with previous research conducted by Wulandari (2012), which concluded that leverage does not significantly affect ISR disclosure. Because investors still depend on other sources of information.

\section{Conclusion}

Based on the research results, it can be concluded that the halal lifestyle, profitability, and leverage in the halal industry sector have a significant effect both simultaneously and partially. That interest-based debt and non-halal income have an impact on firm value, either partially or simultaneously. These results indicate that investors pay more attention to religiousness in choosing investments made in the halal industry sector. Companies in the halal industry sector are also still considering leverage conditions to determine the extent to which ISR disclosures are made. When the level of leverage is high, the company's focus is to show excellent financial performance in the eyes of creditors by generating high profits so that activities that require a lot of costs are tried to be reduced, including the cost of disclosing the ISR.

This research implies that companies making ISR disclosures are influenced by several factors, including halal lifestyle, profitability, and leverage. This study's results can be used as consideration for companies to make ISR disclosures following sharia principles. The company's ISR disclosure level will be of high value if it has low interest-based debt, has a high profitability level, and has little leverage. Besides, companies can improve their financial performance to improve the quality of corporate social responsibility disclosure. For stakeholders, this study will provide information on the level of corporate social responsibility disclosure that can influence the decision making of Muslim stakeholders. Muslim stakeholders can be encouraged to invest in companies with a high level of ISR disclosure because it indicates that they have carried out and managed the company adequately and following sharia principles.

\section{References}

Adlan, M., \& Mawardi, I. (2018). Analisis Pengaruh Utang Berbasis Bunga Dan Pendapatan Non-Halal Terhadap Nilai Perusahaan Emiten Saham Syariah. Jurnal Ekonomi Dan Bisnis Islam, 4(2), 103. https://doi.org/10.20473/jebis.v4i2.10035

Alam, M. M., Akbar, C. S., Shahriar, S. M., \& Elahi, M. M. (2017). The Islamic Shariah principles for investment in stock market. Qualitative Research in Financial Markets, 9(2), $132-146$. https://doi.org/10.1108/QRFM-09-2016-0029

Ayedh, A. M. A., Shaharuddin, A., \& Kamaruddin, M. I. H. (2019). Shariah Screening Methodology: Does It 'Really' Shariah Compliance? Iqtishadia, 12(2), 144. https://doi.org/10.21043/iqtishadia.v12i2.5573

Boubakary, \& Moskolaï, D. D. (2016). The Influence of The Implementation of CSR on Business Strategy: An Empirical Approach Based on Cameroonian Enterprises. Arab Economic and Business Journal, 11(2), 162171. https://doi.org/10.1016/j.aebj.2016.04.001

Cahya, B. T. (2018). Diskursus Islamic Social Reporting. Madania: Jurnal Kajian Keislaman, 22(No.1), 49-62.

Castejón, P. J. M., \& López, B. A. (2016). Corporate Social Responsibility in Family SMEs: A Comparative Study. European Journal of Family Business, 6(1), 21-31. https://doi.org/10.1016/j.ejfb.2016.05.002

Chen, Y. C., Hung, M., \& Wang, Y. (2018). The Effect of Mandatory CSR Disclosure on Firm Profitability and Social externalities: Evidence from China. Journal of Accounting and Economics, 65(1), 169-190. https://doi.org/10.1016/j.jacceco.2017.11.009

Cheng, D., Business, F., Iowa, U., \& Campus, K. (2014). How Creditors Evaluate Financial Statements? The Journal of International Management Studies, 9(1), 156-165.

Chow, C. W., \& Wong-Boren, A. (1987). Voluntary financial disclosure by Mexican corporations. Accounting review, 533-541.

Cooke, T. E. (2009). The Impact of Culture and Governance on Corporate Social Reporting. Journal of Accounting and Public Policy, 35, 472-136.

Dagilienè, L. (2013). The Influence of Corporate Social Reporting to Company's Value in a Developing Economy. Procedia Economics and Finance, 5(13), 212-221. https://doi.org/10.1016/s2212-5671(13)00027-0

Darus, F., Fauzi, H., Purwanto, Y., Yusoff, H., Amran, A., Zain, M. M., ... Nejati, M. (2014). Social Responsibility Reporting of Islamic Banks: Evidence from Indonesia. Journal Business Governance and Ethics, 9(4), 356-380.

Dyck, A., Lins, K. V., Roth, L., \& Wagner, H. F. (2019). Do Institutional Investors Drive Corporate Social Responsibility? International Evidence. Journal of Financial Economics, 131(3), 693-714. https://doi.org/10.1016/j.jfineco.2018.08.013 
El-Halaby, S., \& Hussainey, K. (2015). The Determinants of Social Accountability Disclosure: Evidence from Islamic Banks Around the World. International Journal of Business, 20(3), 202-223.

Frederiksen, T. (2018). Corporate Social Responsibility, Risk and Development in The Mining Industry. Resources Policy, 59, 495-505. https://doi.org/10.1016/j.resourpol.2018.09.004

Gorski, H., Fuciu, M., \& Croitor, N. (2014). Research on Corporate Social Responsibility in the Development Region Centre in Romania. Procedia Economics and Finance, 16, 224-233. https://doi.org/10.1016/s22125671(14)00795-3

Gras-Gil, E., Manzano, M. P., \& Fernández, J. H. (2016). Investigating the Relationship Between Corporate Social Responsibility and Earnings Management: Evidence from Spain. BRQ Business Research Quarterly, 19(4), 289-299. https://doi.org/10.1016/j.brq.2016.02.002

Hadinata, S. (2019). Islamic Social Reporting Index Dan Kinerja Keuangan Pada Perbankan Syariah Di Indonesia. EkBis: Jurnal Ekonomi Dan Bisnis, 2(1), 72. https://doi.org/10.14421/ekbis.2018.2.1.1099

Handayani, Y. I. (2017). Implementation of Islamic Social Reporting in Islamic Banks Malaysia. Journal of Management and Business, 16(2). https://doi.org/10.24123/jmb.v16i2.335

Hafidhuddin, D. (2003). Manajemen syariah dalam praktik. Gema Insani.

Haniffa, R. M., \& Cooke, T. E. (2005). The impact of culture and governance on corporate social reporting. Journal of accounting and public policy, 24(5), 391-430.

Hermawan, M. S., \& Mulyawan, S. G. (2014). Profitability and Corporate Social Responsibility : An Analysis of Indonesia' S Listed Company. Asia Pacific Journal of Accounting and Finance, 3(1), 15-31.

Indrawaty, \& Wardayati, S. M. (2016). Implementing Islamic Corporate Governance (ICG) and Islamic Social Reporting (ISR) in Islamic Financial Institution (IFI). Procedia - Social and Behavioral Sciences, 219, 338 343. https://doi.org/10.1016/j.sbspro.2016.04.042

Innocent, E. C., Ikechukwu, A. C., \& Nnagbogu, E. K. (2014). The Effect of Financial Leverage on Financial Performance: Evidence of Quoted Pharmaceutical Companies in Nigeria. IOSR Journal of Economics and Finance, 5(3), 17-25. https://doi.org/10.9790/5933-0531725

Khairiyani, \& Mubyarto, N. (2019). Does Islamic Corporate Social Responsibility Improve Financial Performance? Jurnal Kajian Ekonomi Islam, 4(2), 205. https://doi.org/10.15548/maqdis.v4i2.259

Kurniawati, M., \& Yaya, R. (2017). Pengaruh Mekanisme Corporate Governance, Kinerja Keuangan dan Kinerja Lingkungan terhadap Pengungkapan Islamic Social Reporting. Jurnal Akuntansi Dan Investasi, 18(2), 163171. https://doi.org/10.18196/jai.180280

Leitoniene, S., \& Sapkauskiene, A. (2015). Quality of Corporate Social Responsibility Information. Procedia Social and Behavioral Sciences, 213, 334-339. https://doi.org/10.1016/j.sbspro.2015.11.547

Lestari, S. (2016). Pengaruh Tingkat Profiabilias, Likuiditas, Leverage, Ukuran Perusahaan dan Umur Perusahaan terhadap Pengungkapan Islamic Social Reporting pada Perbankan Syariah Indonesia Tahun 20102014. Jurnal Akuntansi AKUNESA, 4(2).

Lys, T., Naughton, J., \& Wang, C. (2015). Signaling Through Corporate Accountability Reporting. Journal of Accounting and Economics, 60(1), 56-72. https://doi.org/10.1016/j.jacceco.2015.03.001

Mallin, C., Farag, H., \& Ow-Yong, K. (2014). Corporate Social Responsibility and Financial Performance in Islamic Banks. Journal of Economic Behavior and Organization, 103, 21-38. https://doi.org/10.1016/j.jebo.2014.03.001

Mandina, S., Maravire, C., \& Masere, V. (2014). Effectiveness of Corporate Social Responsibility in Enhancing Company Image. Journal of Applied Business and Economics, 16(3), 152-170.

Md. Hashim, A., Habib, F., Isaacs, Z., \& Gadhoum, M. A. (2017). ISRA-Bloomberg Sharī'ah stock screening and income cleansing methodologies: a conceptual paper. ISRA International Journal of Islamic Finance, 9(1), 27-42. https://doi.org/10.1108/IJIF-07-2017-004

Mubarok, M. S. (2019). The Determinants of Islamic Social Reporting Disclosure and Its Impact on the Profitability of Sharia Banks. Journal of Islamic Economics, Management, and Business, 1(1), 137-172. https://doi.org/10.21580/jiemb.2019.1.1.3742

Mukhtaruddin, Saftiana, Y., \& Dwikatama, P. A. (2018). Firm's Characteristics, Corporate Governance Quality, and Corporate Social Responsibility Disclosure. Sriwijaya International Journal of Dynamic Economics And Business, 2(3), 193-212.

Nainggolan, I. J., \& Handoyo, S. (2019). The Influence of Corporate Social Responsibility (CSR) Disclosures on Corporate Financial Performance with Industrial Types as Moderating Variables. Journal of Accounting Auditing and Business, 2(1), 46. https://doi.org/10.24198/jaab.v2i1.20539

Nazari, J. A., Hrazdil, K., \& Mahmoudian, F. (2017). Assessing Social and Environmental Performance Through Narrative Complexity in CSR Reports. Journal of Contemporary Accounting and Economics, 13(2), 166-178. https://doi.org/10.1016/j.jcae.2017.05.002

Onofrei, M., Tudose, M. B., Durdureanu, C., \& Anton, S. G. (2015). Determinant Factors of Firm Leverage: An Empirical Analysis at Iasi County Level. Procedia Economics and Finance, 20(15), 460-466. https://doi.org/10.1016/s2212-5671(15)00097-0 
Othman, R., Thani, A. M., \& Ghani, E. K. (2009). Determinants of Islamic social reporting among top Shariahapproved companies in Bursa Malaysia. Research Journal of International Studies, 12(12), 4-20.

Platonova, E., Asutay, M., Dixon, R., \& Mohammad, S. (2018). The Impact of Corporate Social Responsibility Disclosure on Financial Performance: Evidence from the GCC Islamic Banking Sector. Journal of Business Ethics, 151(2), 451-471. https://doi.org/10.1007/s10551-016-3229-0

Prasetyoningrum, A. K. (2018). Pengaruh Ukuran Perusahaan, Profitabilitas, Leverage , Efisiensi Biaya , dan Umur Perusahaan terhadap Islamic Social Reporting (ISR) pada Perbankan Syariah di Indonesia. Journal of Islamic Banking and Finance, 2(2), 147-162.

Pratama, N. A., Muchlis, S., \& Wahyuni, I. (2018). Determinan Pengungkapan Islamic Social Reporting (ISR) Pada Perbankan Syariah Dengan Komisaris Independen Sebagai Variabel Moderating. Jurnal Ekonomi, Keuangan, Dan Perbankan Syariah, 1(2), 103-115. https://doi.org/10.24252/al-mashrafiyah.v1i2.4738

Purwadi, M. I. (2017). Konsep dan Implementasi Corporate Social Responsibility (CSR) Pada Perbankan Syariah. Jatiswara, 31(3), 401-415.

Riantani, S., \& Nurzamzam, H. (2015). Analysis of Company Size, Financial Leverage, and Profitability and Its Effect To CSR Disclosure. Jurnal Dinamika Manajemen, 6(2), $203-213$. https://doi.org/10.15294/jdm.v6i2.4308

Rizfani, K. N., \& Lubis, D. (2019). Pengungkapan Islamic Social Reporting pada Perusahaan di Jakarta Islamic Index. Al-Muzara'ah, 6(2), 103-116. https://doi.org/10.29244/jam.6.2.103-116

Rodriguez-Fernandez, M. (2016). Social Responsibility and Financial Performance: The Role of Good Corporate Governance. Cuadernos de Economía y Dirección de La Empresa, 19(2), 137-151. https://doi.org/10.1016/j.brq.2015.08.001

Salehi, M., Tarighi, H., \& Rezanezhad, M. (2019). Empirical Study on the Effective Factors of Social Responsibility Disclosure of Iranian Companies. Journal of Asian Business and Economic Studies, 26(1), 3455. https://doi.org/10.1108/jabes-06-2018-0028

Sanclemente-Téllez, J. C. (2017). Marketing and Corporate Social Responsibility (CSR) Moving between Broadening the Concept of Marketing and Social factors as a Marketing Strategy. Spanish Journal of Marketing - ESIC, 21, 4-25. https://doi.org/10.1016/j.sjme.2017.05.001

Santoso, A. L., \& Dhiyaul-Haq, Z. M. (2017). Determinan Pengungkapan Islamic Social Reporting pada Bank Umum Syariah di Indonesia. Jurnal Dinamika Akuntansi Dan Bisnis, 4(2), $125-142$. https://doi.org/10.24815/jdab.v4i2.6421

Sarkis, N., \& Daou, L. (2013). Giving Back to the community, an Obligation or an Option Today? - Case of the Educational Sector in Lebanon. International Strategic Management Review, 1(2), 59-64. https://doi.org/10.1016/j.ism.2013.09.001

Sila, I., \& Cek, K. (2017). The Impact of Environmental, Social and Governance Dimensions of Corporate Social Responsibility: Australian Evidence. Procedia Computer Science, 120, 797-804. https://doi.org/10.1016/j.procs.2017.11.310

Soemitra, A. (2016). Higher Objectives of Islamic Investment Products: Islamizing Indonesian Capital Market. Studia Islamika, 23(2), 237-269. https://doi.org/10.15408/sdi.v23i2.2408

Šntaitė-Petkevičienė, M. (2015). CSR Reasons, Practices, and Impact to Corporate Reputation. Procedia Social and Behavioral Sciences, 213, 503-508. https://doi.org/10.1016/j.sbspro.2015.11.441

Sulistyawati, A. I., \& Yuliani, I. (2017). Pengungkapan Islamic Reporting Pada Indeks Saham Syariah Indonesia. Jorunal Of Accounting \& Finance, 13(2), 15-27.

Widayati, A. D., \& Sukmana, R. (2017). Difference Analysis of Social Performance With The Islamic Social Reporting (ISR) in Syariah Banking That Is in Indonesia and Malaysia. AFEBI Islamic Finance and Economic Review, 1(1), 53-62.

Wulandari, F. (2015). Pengaruh Profitabilitas, Ukuran Perusahaan, Kinerja Lingkungan, dan Leverage terhadap Pengungkapan Islamic Social Reporting (Doctoral dissertation, Universitas Muhammadiyah Surakarta).

Wuttichindanon, S. (2017). Corporate Social Responsibility Disclosure-Choices of Report and its Determinants: Empirical Evidence from Firms listed on the Stock Exchange of Thailand. Kasetsart Journal of Social Sciences, 38(2), 156-162. https://doi.org/10.1016/j.kjss.2016.07.002

Yusuf, M. Y. (2017). Islamic Corporate Social Responsibility (I-CRS) Pada Lembaga Keuangan Syariah (LKS): Teori Dan Praktik. Prenada Media.

Zain, M. M., Darus, F., \& Ramli, A. (2015). Islamic Ethical Practices and the Marketplace: Evidence from Islamic Financial Institutions. Procedia Economics and Finance, 28, 266-273. https://doi.org/10.1016/s22125671(15)01110-7

Zheng, P., \& Ren, C. (2019). Voluntary CSR Disclosure, Institutional Environment, and Independent Audit Demand. China Journal of Accounting Research, 12(4), 357-377. https://doi.org/10.1016/j.cjar.2019.10.002 